Keywords:

Plant ecology

Geoecology

Floristic composition, Environmental variables

Histórico:

Recebido 01/12/2014 Aceito 15/1 1/2015

Palavras chave:

Ecologia vegetal

Geoecologia

Composição florística

Variáveis ambientais

Correspondência: morel.jean@gmail.com
Jean Daniel Morel', Rubens Manoel dos Santos', Marco Aurélio Leite Fontes', Paulo Oswaldo Garcia², Fernanda Maria de Souza'

\section{FLORISTIC COMPARISON BETWEEN TWO TREE COMMUNITIES ASSOCIATED WITH HABITAT DESCRIPTOR VARIABLES}

ABSTRACT: The knowledge about the influence of habitat variables is essential to understand the underlying ecological patterns in vegetation. This study compared the floristic composition of two forest communities located in different altitudes. Associated with this comparison, we used a methodology where habitat descriptor variables were scaled and interpreted by the biotic set sampled. We constructed one matrix with scores given to physical, biotic, vegetation, and anthropogenic variables in the field and one matrix with the species sampled and performed multivariate analyses. We found that the floristic communities differ between the different altitudes and that the methodology used showed significant variables for the ecological characterization of the sampled habitat.

\section{COMPARAÇÃO FLORÍSTICA ENTRE DUAS COMUNIDADES ARBÓREAS ASSOCIADA A VARIÁVEIS DESCRITORAS DO AMBIENTE}

RESUMO: O conhecimento sobre a influência das variáveis ambientais é essencial para que se compreenda os padrões ecológicos atuantes sobre a vegetação. Este trabalho comparou a composição florística de duas comunidades florestais localizadas em diferentes altitudes. Associada a essa comparação, foi utilizada uma metodologia onde variáveis descritoras do ambiente foram escalonadas e interpretadas junto ao conjunto biótico amostrado. Através de uma matriz, com a pontuação dada em campo para variáveis físicas, bióticas, da estrutura da vegetação e de antropização, e de outra, contendo as espécies amostradas, análises multivariadas foram utilizadas. Constatou-se que as comunidades diferem floristicamente entre as diferentes altitudes e que a metodologia utilizada indicou variáveis importantes para a caracterização ecológica dos ambientes amostrados. 


\section{INTRODUCTION}

The distribution of plant species is determined by physicochemical and biological factors, and by a combination of these factors (CONTI; FURLAN, 2009; COX; MOORE, $20 \mathrm{II}$ ). At the macroscale, climate is the major determinant of plant distribution, as it provides different conditions of temperature and precipitation (WHITTAKER, 1975; WALTER, 1985). Conversely, variations in topography and soils are the main determinants of vegetation at smaller scales (NEWTON, 2007; FERREIRA JÚNIOR et al., 2009). Moreover, interactions between species can also affect plant distribution, as the establishment and growth of several species can be inhibited or favored depending on the distribution of other plant species (KENT; COKER, 1992; SANTOS et al., 2012). Natural or anthropogenic disturbance events also cause changes in vegetation and may cause changes in the structure and dynamics of plant communities and populations (BEGON et al., 2007; GHAZOUL; SHEIL, 20I0).

The influence of environmental variables on plant species may result in different distribution patterns that vary over time and space (MEIRELES et al., 2008; SANTOS et al., 20I2). Variation in species distributions requires that the combined effects of vegetation and environmental variables be evaluated together (TER BRAAK, 1987), taking into account that some variables are more responsive than others when a particular group of species is considered. Thus, it is often necessary to combine methods with floristic surveys and forest structure studies to elucidate ecological patterns and processes. Nevertheless, some of the information that characterizes the habitat remains unknown due to measuring difficulties or the high cost of quantification.

This study aimed to evaluate the floristic variation of two plant communities at different altitudes from a qualitative method for habitat characterization that uses a set of scaled variables. We expect that this method may serve as support information for the evaluated communities and provides additional parameters to help explain the ecological patterns of vegetation.

\section{MATERIAL AND METHODS}

We listed characteristics of native forest habitats based on a literature review, considering biotic and abiotic factors, arboreal physiognomy, and human disturbances. We selected 20 variables that were treated as habitat descriptor variables (HDV). These variables were grouped into the categories described below. A Abiotic descriptors: Al Slope, A2 Rocky outcrops, A3 Leaf litter deposition, A4 Humidity, and A5 Wind exposure. B Biotic descriptors: BI Bamboo density, B2 Bromeliad density, B3 Orchid density, B4 Bryophyte density, B5 Lichen density, and B6 Liana density. C Arboreal/sub-arboreal vegetation descriptors: CI Density of individuals, C2 Size of individuals, C3 Canopy stratification, C4 Canopy openness, and C5 Understory stratification. D Anthropization descriptors: DI Abundance of cut stumps, D2 Abundance of trails, D3 Abundance of cattle feces, and D4 Abundance of fire evidence.

With the selected variables we constructed a semiquantitative matrix for survey in the field, as in the methods of phenological assessment (FOURNIER, 1974; WHEELWRIGHT, 1985). We used a interval scale $(0-4)$ to infer the influence of variables on sampling units, with 0 indicating the lack of influence, I indicating a I - 25\% influence, 2 to 26 - $50 \%$ influence, 3 to 5 I - $75 \%$ influence, and 4 indicating a $76-100 \%$ influence.

Two areas were sampled in the same region, in the municipality of Itamonte, on a hillside of the Mantiqueira range, southern Minas Gerais state, Brazil. The floristic composition was sampled at $1500 \mathrm{~m}$ and $1900 \mathrm{~m}$ above sealevel (a.s.I.), in 30 sample points ( 15 in each area) delimited by a circle with $10 \mathrm{~m}$ radius, totaling 0,942 ha of sampling. At each sample point, all arboreal and sub-arboreal species were sampled, considering all individuals over Im high. Simultaneously to the vegetation survey, habitat descriptor variables were scaled using the habitat matrix.

Detrended Correspondence Analysis (DCA) (TER BRAAK, 1987) from a binary presence-absence species matrix and a categorical matrix of altitude was used to check the effect of altitude on the distribution of species independent of other habitat variables. Canonical Correspondence Analysis (CCA) (TER BRAAK, 1987) was used to infer the influence of HDVs on the distribution of species. In this case, in addition to the species matrix, we constructed a matrix with HDV data and used the Monte Carlo test to test the significance of correlations. CCA was performed on all habitat variables (CCAI) and on variables with correlation above 0.7 with the vegetation gradient (CCA2), considering the first two axes. The analyses were performed using PC-ORD 5.10 for Windows software (MCCUNE; MEFFORD, 2006).

\section{RESULTS AND DISCUSSION}

In total, I33 species were sampled, 98 at 1500 m and 78 at $1900 \mathrm{~m}$. Of the total species sampled, 55 were unique to the lower altitude area and 35 were sampled in the higher altitude area only. These results are in accordance with the notion that species richness decreases with altitude in tropical forests (GENTRY, 1995; RAHBEK, I995; ADAMS, 2010; SCHEER et al., 20I I). The list of species is shown in Table I. In addition to species surveys, understanding the influence of habitat variables on the organization of biological communities helps corroborate the patterns observed and provides the delimitation of groups and the knowledge of the relationships between these groups and their habitats. The survey of the variables (Table 2 ) provides a greater basis for 


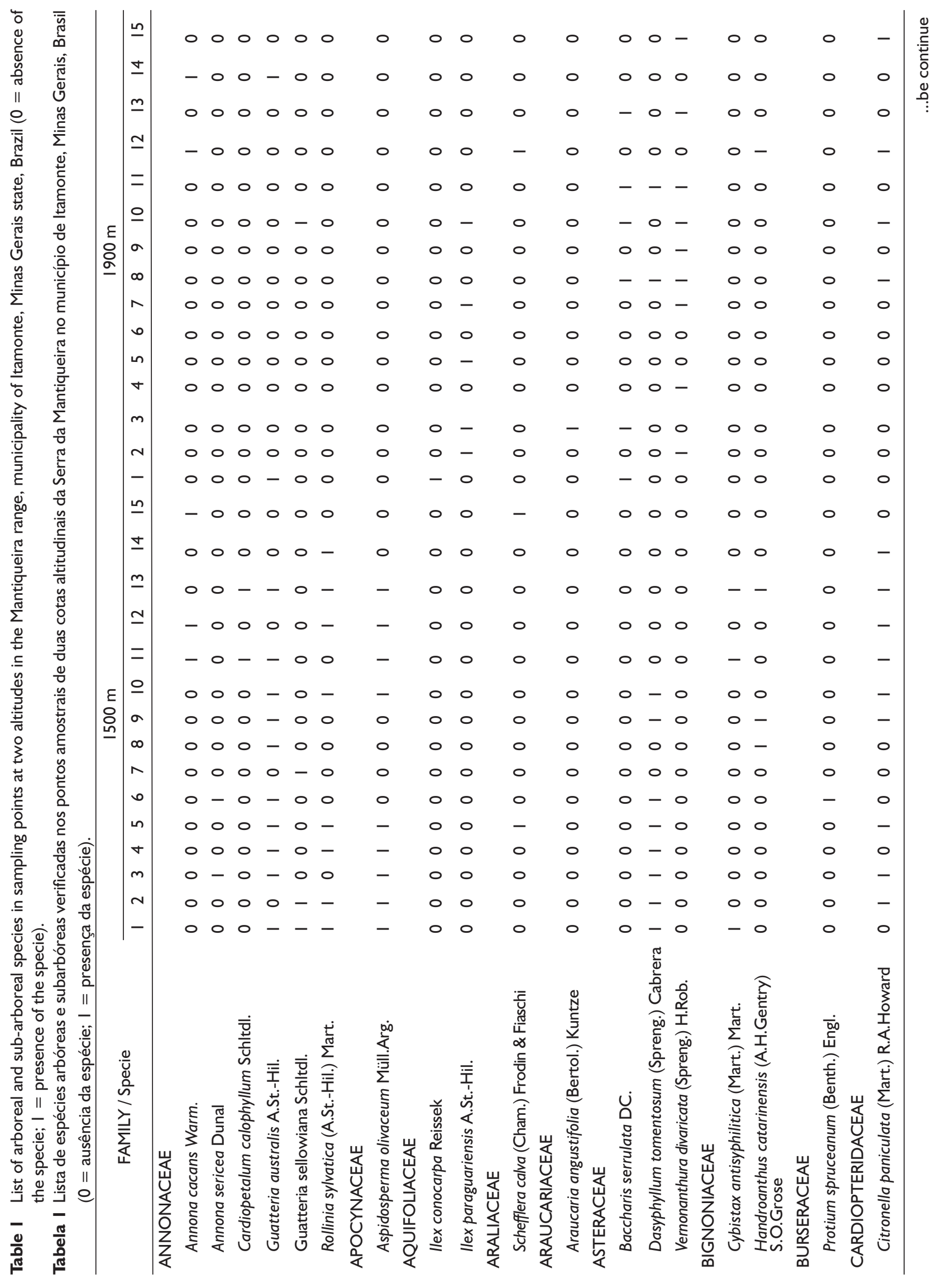




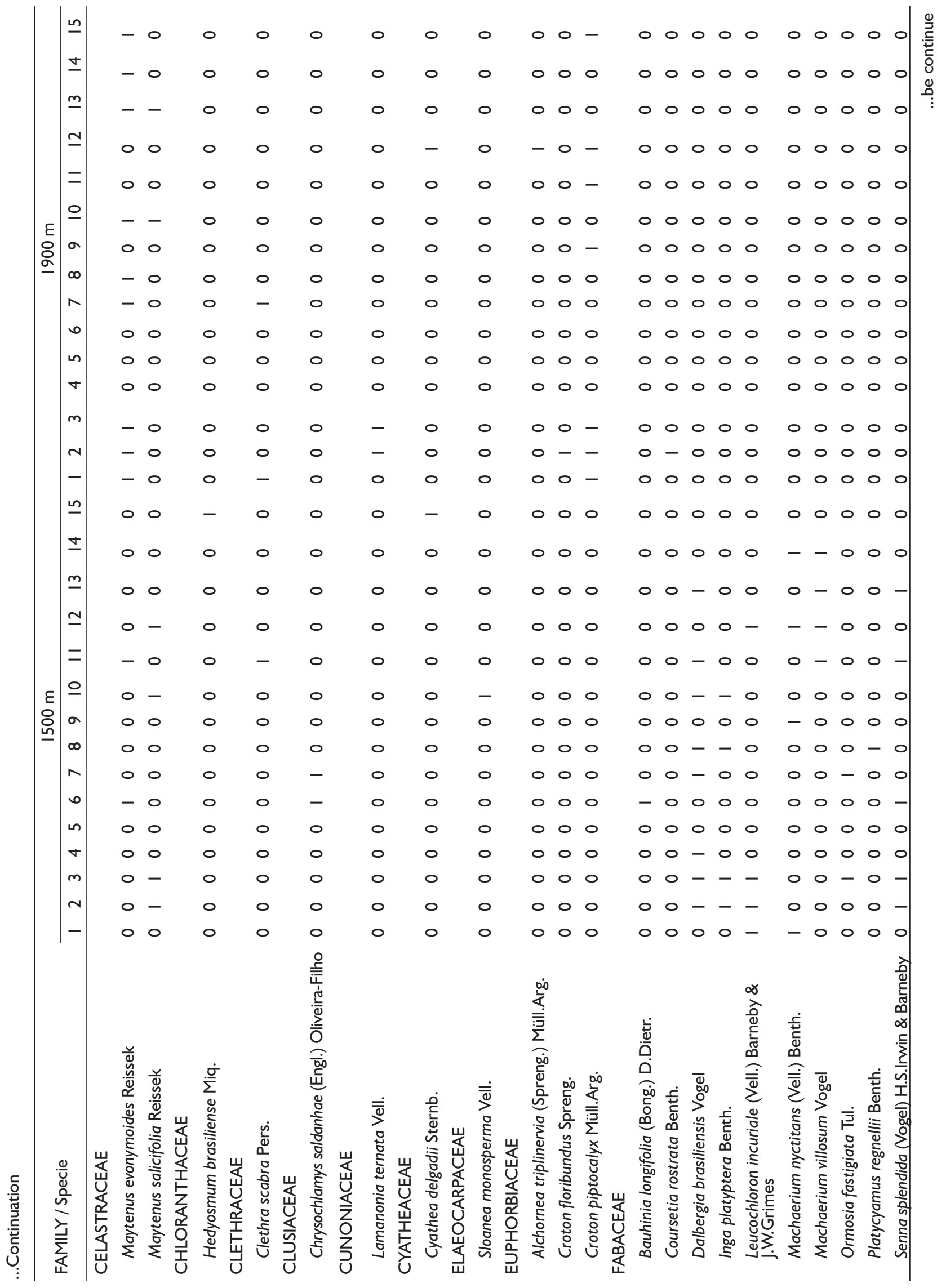




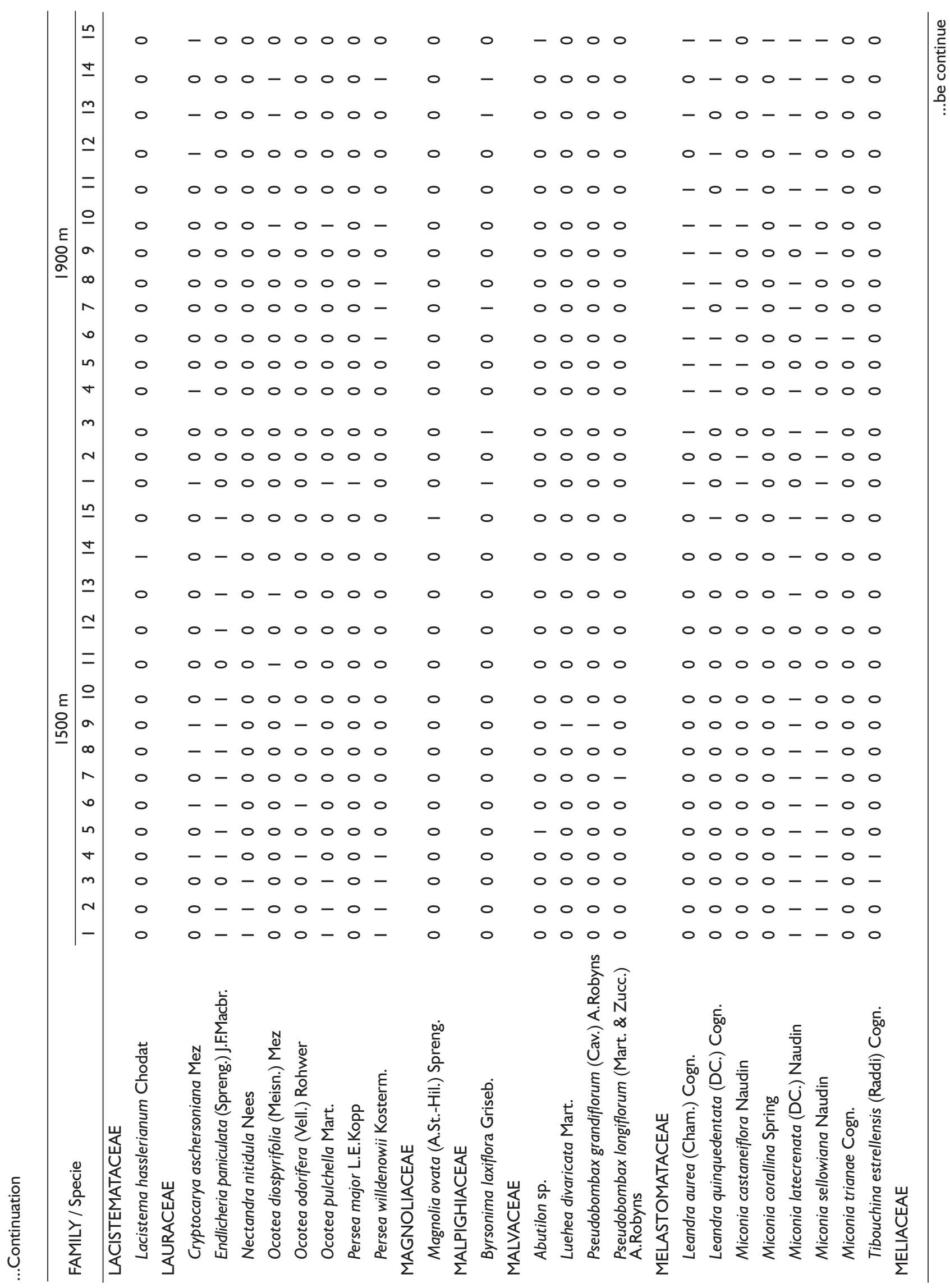




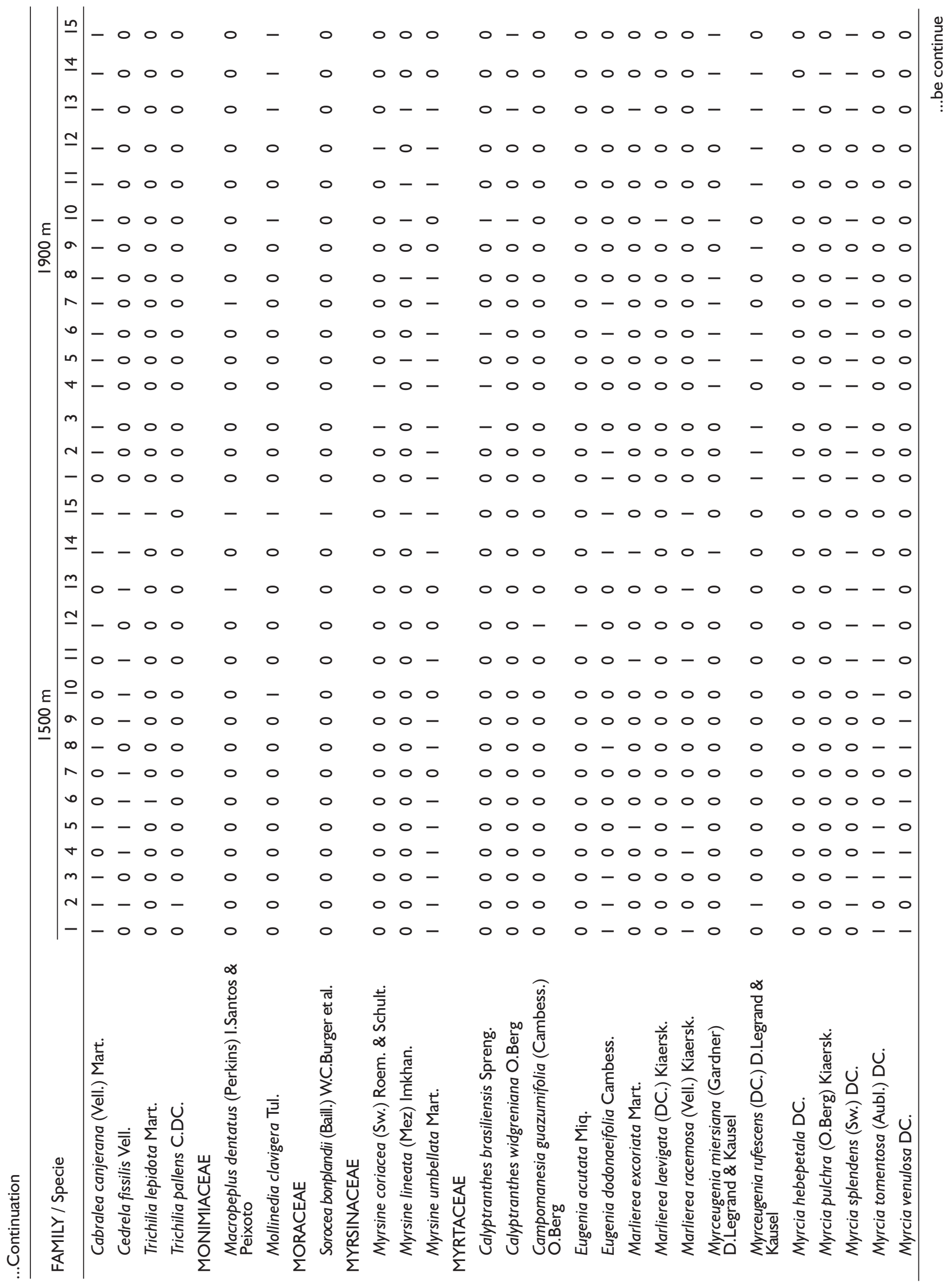




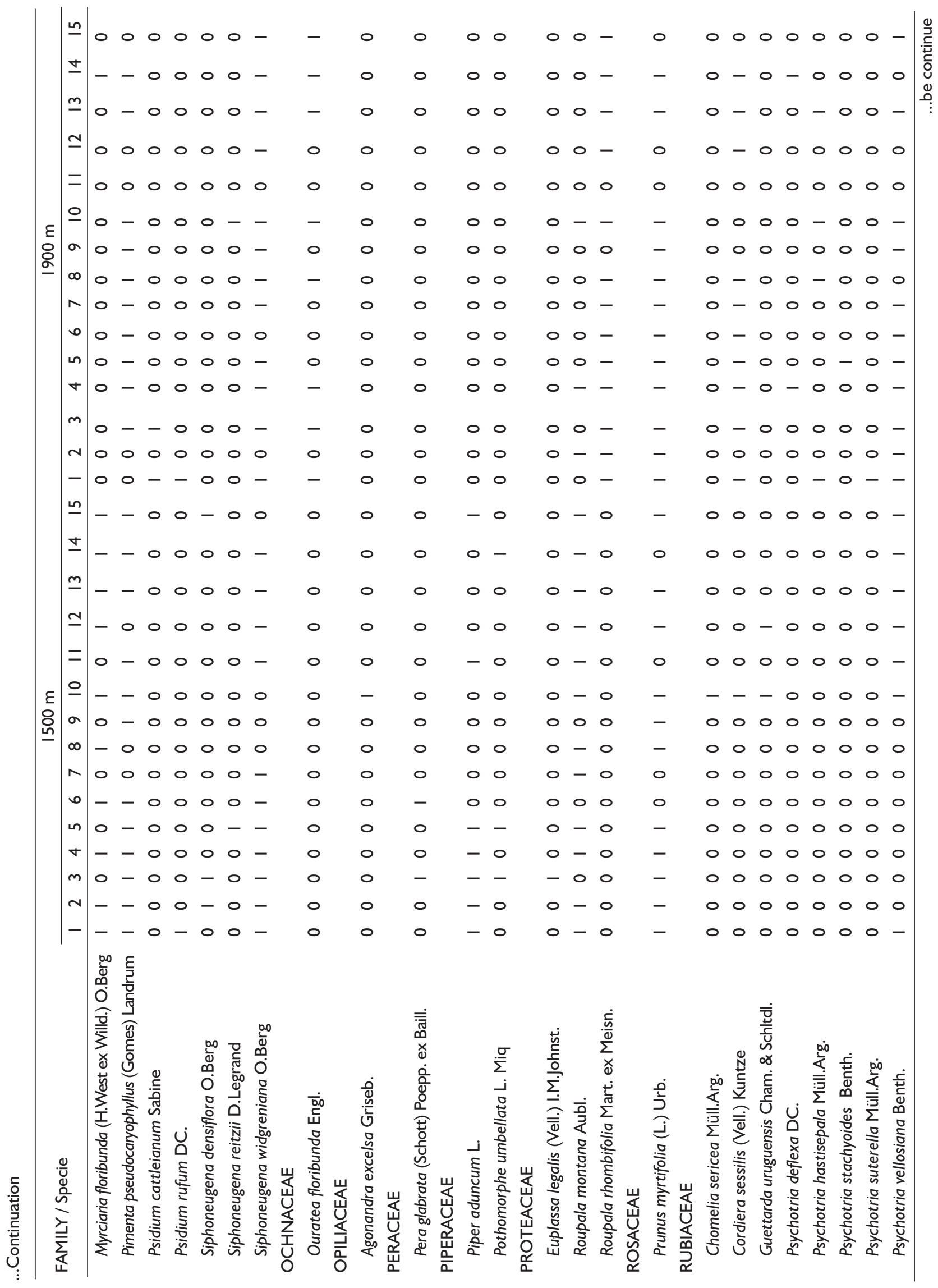




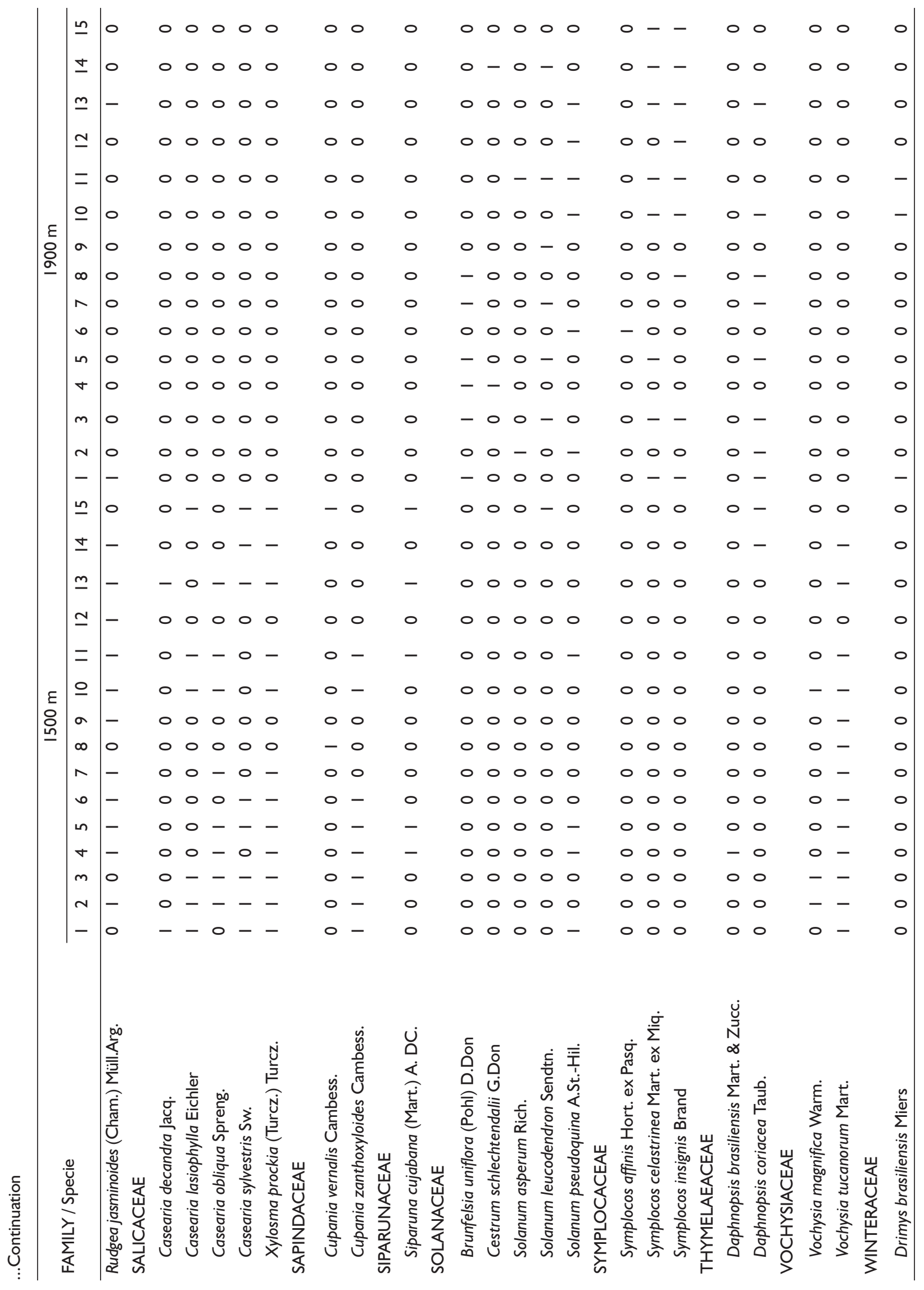









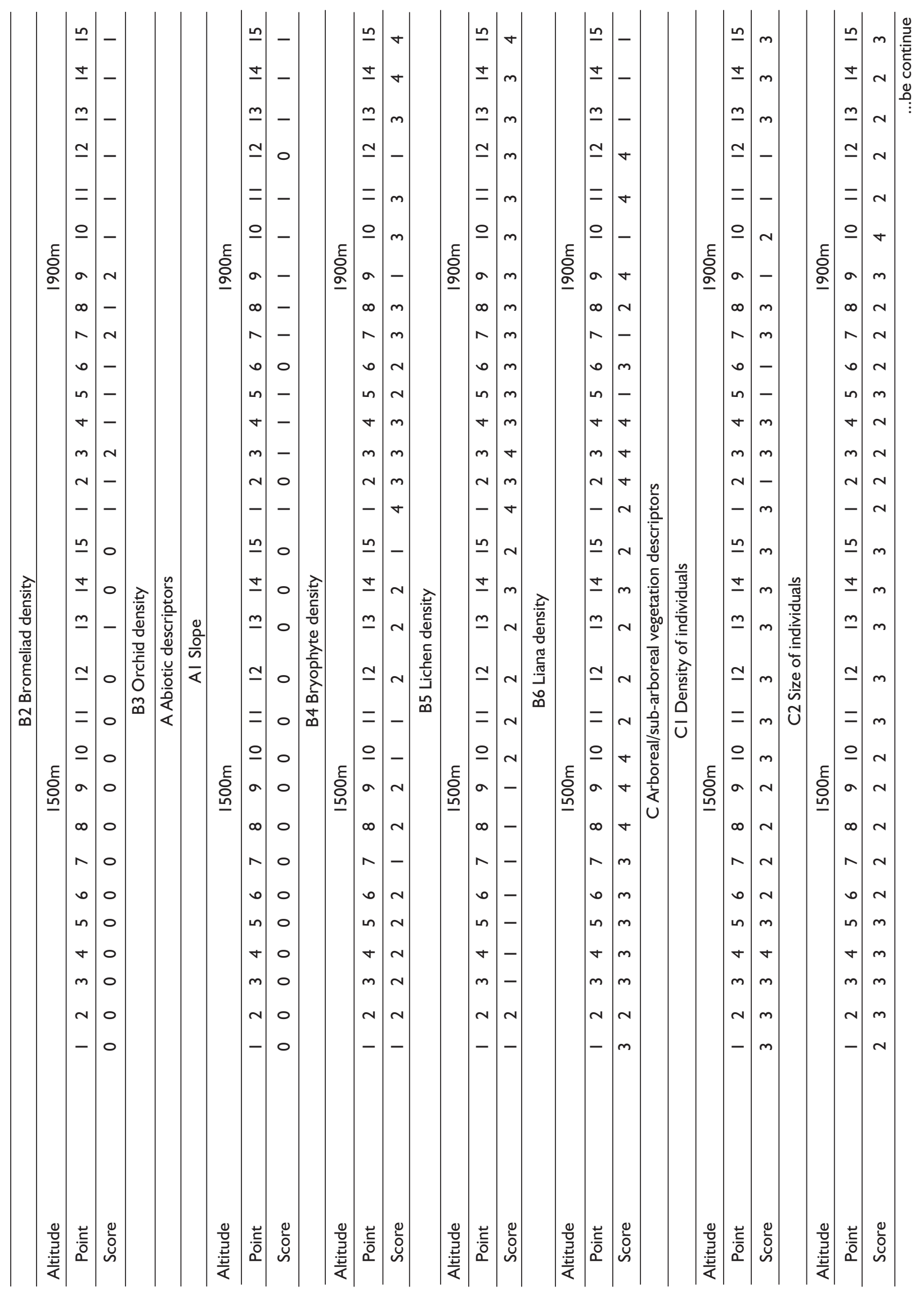




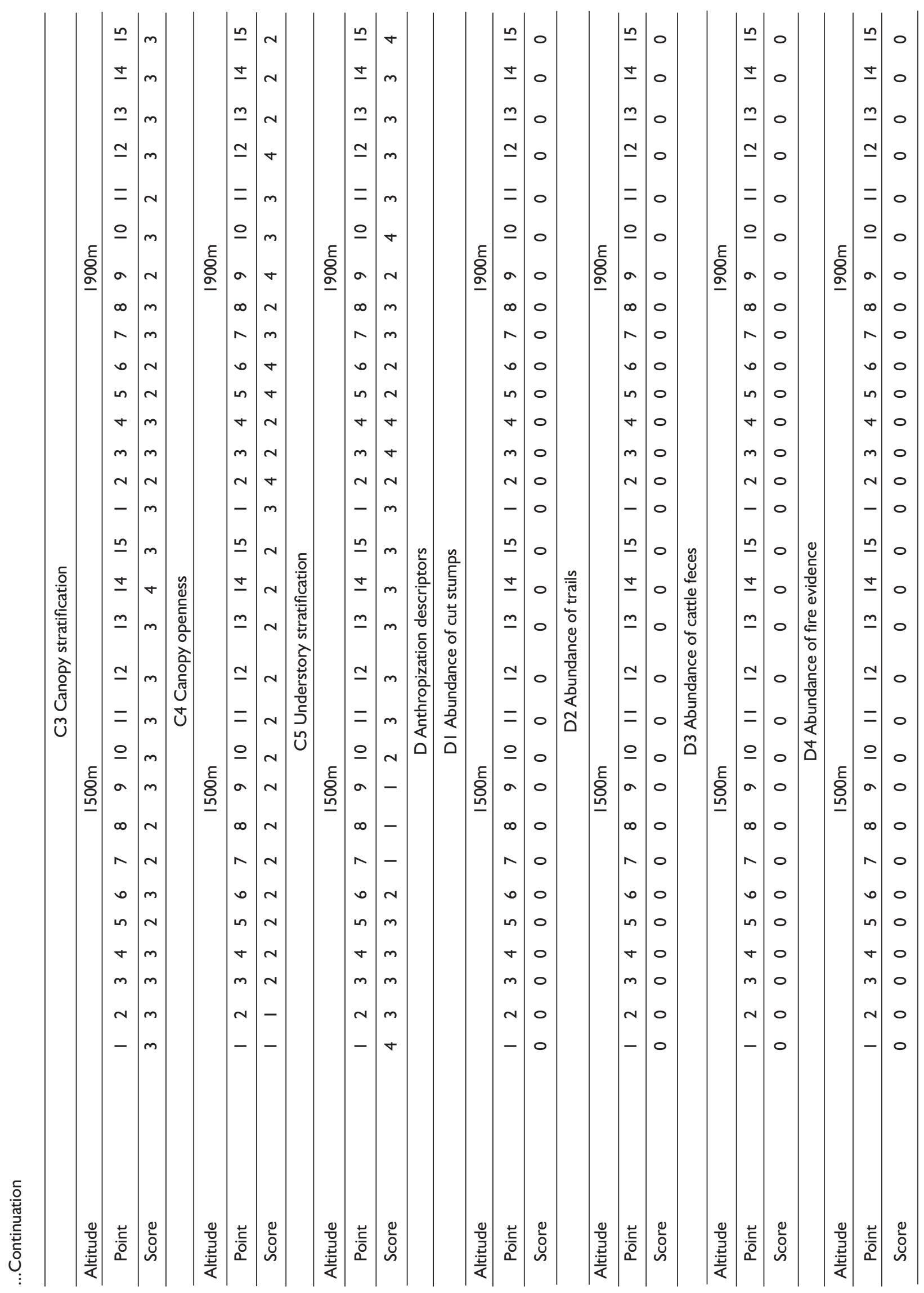


inferences and better understanding of the influence of the variables used on vegetation patterns.

Ordination analysis showed that arboreal and sub-arboreal vegetation differed between altitudes (Figure I). Axis I, which represents the main floristic gradient, indicates that each altitude has a different group of species. The eigenvalue of this axis (0.558) shows a long gradient, indicating the occurrence of species unique to each altitude (TER BRAAK, 1995). Moreover, there is a greater cohesion in the group of species from 1900 $\mathrm{m}$ a.s.l. due to the presence of species typical of higher elevations such as Byrsonima laxiflora, Drimys brasiliensis, and Symplocos celastrinea, in addition to the genus Ilex (OLIVEIRA FILHO; FONTES, 2000).

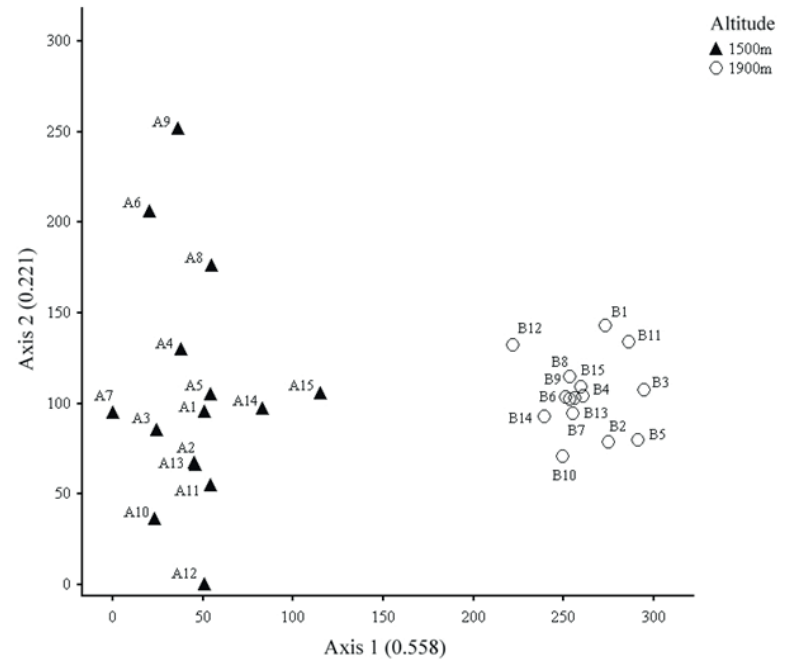

Figure I Detrended Correspondence Analysis (DCA) diagram of the distribution of arboreal and sub-arboreal species sampled at two altitudes in the Mantiqueira range, municipality of Itamonte, Minas Gerais state, Brazil. A $=$ points at $1500 \mathrm{~m}$; and $\mathrm{B}=$ points at $1900 \mathrm{~m}$.

Figura I Diagrama gerado pela Análise de Correspondência Retificada para a distribuição das espécies arbóreas e subarbóreas amostradas em duas cotas altitudinais da Serra da Mantiqueira no município de Itamonte, Minas Gerais, Brasil.

The difference in species composition between the two areas sampled was due to the differential distribution of species along the altitudinal gradient. Nevertheless, altitudinal variations comprise a complex set of variables related to temperature, air humidity, water availability, wind exposure, in addition to soil depth and drainage classes (CARVALHO et al., 2005; HOMEIER et al., 20I0; BLUNDO et al., 20I2).

Canonical Correspondence Analyses showed significant correlations between habitat variables and community organization (Table 3). All habitat descriptor variables (HDV), except for the four anthropogenic variables (scored value 0 ), were used in CCAI, totaling 16 quantitative variables and one categorical variable (altitude). This analysis showed that the distribution of species correlated significantly with HDVs $(p<0.01)$.

Table 3 Summary of Canonical Correspondence Analysis (CCA) results of arboreal and sub-arboreal species sampled at two altitudes in the Mantiqueira range, municipality of Itamonte, Minas Gerais state, Brazil.

Tabela 3 Resumo dos resultados da Análise de Correspondência Canônica para as espécies arbóreas e subarbóreas amostradas em duas cotas altitudinais da Serra da Mantiqueira no município de Itamonte, Minas Gerais, Brasil.

P Axis I Axis 2 Axis 3

CCAI

Monte Carlo test

0.001

Eigenvalue

$\begin{array}{lll}0.548 & 0.258 & 0.221\end{array}$

Species-environment

correlation

$0.996 \quad 0.976 \quad 0.978$

Cumulative percentage variance

of species presence data

$13.40 \quad 19.70 \quad 25.10$

Cumulative percentage variance

of species-environment

$18.80 \quad 27.20 \quad 34.90$

CCA2

Monte Carlo test

0.001

Eigenvalue

$\begin{array}{lll}0.523 & 0.234 & 0.171\end{array}$

Species-environment correlation

$\begin{array}{lll}0.978 & 0.958 & 0.969\end{array}$

Cumulative percentage variance of species presence data

$12.80 \quad 18.50 \quad 22.70$

Cumulative percentage variance of species-environment

$42.80 \quad 61.10 \quad 75.60$

CCA2 was calculated using the five variables that correlated with the vegetation gradient $(r>0.7$, considering the first two axes): humidity, wind exposure, bromeliad density, orchid density, and lichen density (Table 4). According to CCA2, axis 2 showed the correlation between humidity with the distribution of species sampled at $1500 \mathrm{~m}$ (Figure 2).

It should be noted that humidity, which is important for temperature regulation and nutrient transport in soil (CONTI; FURLAN, 2009), favors the establishment of species adapted to the microclimate provided by it. This effect was observed in the area at $1500 \mathrm{~m}$, which was close to a water course. In fact, this variable probably favored the establishment of species such as Casearia obliqua, Endlicheria paniculata, Luehea divaricata, Magnolia ovata, Platycyamus regnellii, Protium spruceanum, and Vochysia magnifica, whose 
occurrences were previously associated with humid habitats (OLIVEIRA FILHO; FLUMINHAN FILHO, 1999; BOTREL et al., 2002; SOUZA et al., 2003; CARVALHO et al., 2005; ROCHA et al., 2005).

The variable wind exposure, most associated with the axis $\mathrm{I}$, is correlated to the distribution of species at $1900 \mathrm{~m}$. This variable is associated with high altitudes and acts on the composition, structure and distribution of tree species in communities located in elevated areas (NEWTON, 2007; HOMEIER et al., 2010 ; BERTONCELLO et al., 20I I). In study along a 2.5 $\mathrm{km}$ transect ranging in tropical montane cloud forests in north-western Costa Rica, Häger (2010) considered the wind exposure as a key variable to tree species turnover along environmental gradients on a local scale, therefore the constancy of the wind acts upon the air temperature and the cloudiness. Considering the ecology of cloud forests, the author also points out that these variables determine the occurrence of species, including endemic species, in habitat with strict conditions. (HÄGER, 20I0).

Between the two communities evaluated the wind exposure should be acting in this way, contributing to the differentiation of the area located $1900 \mathrm{~m}$ a.s.I. In addition to the relationship with altitude wind exposure may also be associated with the occurrence of bamboos and canopy openness. Despite not entering in the inclusion criteria of CCA2, these two variables showed significant correlations with axis I to the area located at $1900 \mathrm{~m}$.

Another variables more strongly associated with species distributions at $1900 \mathrm{~m}$ with greater amplitude along axis 2 were orchid, bromeliad and lichen density, all of which typical of montane forests (ADAMS, 20I0; GHAZOUL; SHEIL, 20I0; SCHEER et al., 20II). The presence of these botanicals groups in montane forests is related to the constant water supply provided by the cloudness, which makes its typical species of this habitat type (ADAMS, 20I0; ACHARYA, 20II; BLUM et al., 20I I; KRÖMER et al., 20I3; DYMYTROVA et al., 2014). Thus, some tree species characteristics of high altitude as Ilex paraguariensis, Croton piptocalyx, Leandra aurea, Ouratea floribunda, Roupala rhombifolia e Symplocos insignis, exclusive from community located at $1900 \mathrm{~m}$ and sampled in majority points, may have their local occurrence related to microclimate conditions.

The use of HDVs explained a large part of the variance of the data. The cumulative variance of the first three axes in CCA2 was $22.7 \%$ for species data and $75.6 \%$ for the relationship between species and habitat variables (Table 3). Prado et al. (2002) argued that, in many cases, the first two or three axes explain a large
Table 4 Correlations between habitat variables and the first three axis in the Canonical Correspondence Analyses (CCAI) for communities located at two altitudes in the Mantiqueira range, municipality of Itamonte, Minas Gerais state, Brazil.

Tabela 4 Correlações entre variáveis ambientais e os três primeiros eixos da Análise de Correspondência Canônica (CCAI) para comunidades localizadas em duas altitudes na Serra da Mantiqueira, no município de Itamonte, Minas Gerais, Brasil.

\begin{tabular}{lllll}
\hline \multirow{2}{*}{ Variable } & \multicolumn{3}{c}{ Correlations } \\
\cline { 3 - 5 } & & Axis I & Axis 2 & Axis 3 \\
\hline AI & Slope & 0.256 & -0.288 & -0.056 \\
A2 & Rocky outcrops & 0.390 & -0.105 & 0.296 \\
A3 & Leaf litter deposition & 0.040 & -0.196 & -0.295 \\
A4 & Humidity & 0.301 & 0.783 & 0.155 \\
A5 & Wind exposure & -0.725 & 0.223 & -0.014 \\
BI & Bamboo density & -0.387 & -0.090 & -0.565 \\
B2 & Bromeliad density & -0.855 & -0.092 & 0.015 \\
B3 & Orchid density & -0.857 & -0.238 & 0.067 \\
B4 & Bryophyte density & -0.678 & -0.385 & -0.054 \\
B5 & Lichen density & -0.886 & -0.058 & 0.219 \\
B6 & Liana density & 0.249 & -0.016 & -0.467 \\
C1 & Density of individuals & 0.358 & -0.086 & 0.404 \\
C2 & Size of individuals & 0.222 & 0.161 & 0.446 \\
C3 & Canopy stratification & 0.164 & -0.050 & 0.245 \\
C4 & Canopy openness & -0.612 & 0.103 & -0.151 \\
C5 & Understory stratification & -0.299 & 0.026 & 0.483 \\
\hline
\end{tabular}



Figure 2 Canonical Correspondence Analysis (CCA) diagram of the distribution of arboreal and sub-arboreal species sampled at two altitudes in the Mantiqueira range, municipality of Itamonte, Minas Gerais state, Brazil. A $=$ points at $1500 \mathrm{~m}$; and $\mathrm{B}=$ points at $1900 \mathrm{~m}$.

Figura 2 Diagrama gerado pela Análise de Correspondência Canônica para a distribuição das espécies arbóreas e subarbóreas amostradas em duas cotas altitudinais da Serra da Mantiqueira no município de Itamonte, Minas Gerais, Brasil. 
part of the variance (60-90\%), which enables to use the results to describe the system without significant loss of information. Thus, even when the first two axes only are considered, the percentage values obtained in this study are high.

We consider that the use of HDVs provided parameters that allowed us to interpret and discuss the floristic composition of the sampled communities more widely, since in addition to the altitude, other habitat features were added. With the largest number of variables were obtained parameters allowed to extend the discussion. In addition to corroborate the influence of altitude the variables used showed characteristics of communities that extended their ecological interpretation.

\section{ACKNOWLEDGMENTS}

We are grateful to the owners and coordinators at RPPN Altomontana, where filed work was conducted, and to students for their help with field work. We are also grateful to Coordination for the Improvement of Higher Education Personnel CAPES, for the doctoral scholarship given to the first author, to Foundation for Research of Minas Gerais State - FAPEMIG, and the Post Graduate Program in Forestry at UFLA.

\section{REFERENCES}

ACHARYA, K. P.; VETAAS, O. R.; BIRKS, H. J. B. Orchid species richness along Himalayan elevational gradients. Journal of Biogeography, Oxford, v. 38, n. 9, p. I82I-I833, set. 201 I.

ADAMS, J. Vegetation-climate interaction: how plants make the global environment. 2.ed. Chichester, UK: Springer Praxis Books, 2010. 266 p.

BEGON, M.; TOWNSEND, C. R.; HARPER, J. L. Ecologia: de indivíduos a ecossistemas. 4. ed. Porto Alegre: Artmed, 2007. $740 \mathrm{p}$.

BERTONCELLO, R.; YAMAMOTO, K.; MEIRELES, L. D.; SHEPHERD, G. J. A phytogeographic analysis of cloud forests and other forest subtypes amidst the Atlantic forests in south and southeast Brazil. Biodiversity and Conservation, Amsterdam, v. 20, n. I4, p. 34I3-3433, dez. 201 I.

BLUM, C. T.; RODERJAN, C. V.; GALVÃO, F. Composição florística e distribuição altitudinal de epífitas vasculares da Floresta Ombrófila Densa na Serra da Prata, Morretes, Paraná, Brasil. Biota Neotropica, São Paulo, v. I I, n. 4, p. |4|-|49, out. 20II.
BLUNDO, C.; MALIZIA, L. R.; BLAKE, J. G.; BROWN, A. D. Tree species distribution in Andean forests: influence of regional and local factors. Journal of Tropical Ecology, Cambridge, v. 28, n. I, p. 83-95, jan. 2012.

BOTREL, R. T.; OLIVEIRA FILHO, A. T. de; RODRIGUES, L.; CURI, N. Influência do solo e topografia sobre as variações da composição florística e estrutural da comunidade arbóreo-arbustiva de uma floresta estacional semidecidual em Ingaí, MG. Revista Brasileira de Botânica, São Paulo, v. 25, n. 2, p. 195-2।3, 2002.

CARVALHO, D. A.; OLIVEIRA FILHO, A. T.; BERG, E. V. D.; FONTES, M. A. L.; VILELA, E. A.; MARQUES, J. J. S. M.; CARVALHO, W. A. C. Variações florísticas e estruturais do componente arbóreo de uma floresta ombrófila altomontana às margens do rio Grande, Bocaina de Minas, MG, Brasil. Acta Botanica Brasilica, São Paulo, v. 19, n. I, p. 9I-109, jan./mar. 2005.

CONTI, J. B.; FURLAN, S. A. Geoecologia: o clima, os solos e a biota. In: ROSS, J. L. S. (Org.). Geografia do Brasil. 6. ed. São Paulo: Editora da Universidade de São Paulo, 2009. p. 67-208.

COX, C. B.; MOORE, P.D. Biogeografia: uma abordagem ecológica e evolucionária. 7. ed. Rio de Janeiro: LTC, 20II. 398 p.

DYMYTROVA, L.; NADYEINA, O.; HOBI, M. L.; CHEIDEGGER, C. Topographic and forest-stand variables determining epiphytic lichen diversity in the primeval beech forest in the Ukrainian Carpathians. Biodiversity and Conservation, Amsterdam, v. 23, n. 6, p. I367-I394, jun. 2014.

FERREIRA JÚNIOR, W. G.; SCHAEFER, C. E. G. R.; SILVA, A. F. Uma visão pedogeomorfológica sobre as formações florestais da Mata Altântica. In: MARTINS, S. V. (Ed.). Ecologia de florestas tropicais do Brasil. Viçosa: Editora UFV, 2009. cap. 4, p. 109-142.

FOURNIER, L. A. Un metodo cuantitativo para la medición de características fenológicas en arboles. Turrialba, San José, v. 24 , n. 4 , p. 422-423, Oct./Dec. 1974.

GHAZOUL, J.; SHEIL, D. Tropical rain forest: ecology, diversity, and conservation. Oxford: Oxford University Press, $2010.516 \mathrm{p}$.

GENTRY, A. H. Patterns of diversity and floristic composition in neotropical montane forest. In: CHURCHILL, S. P.; BASLEV, H.; FORERO, E.; LUTEYN, J. L. (Ed.). Biodiversity and conservation of neotropical montane forest. New York: The New York Botanical Garden Press, 1995. p. 103-I 26.

HÄGER, A. The effect of climate and soil conditions on tree species turnover in a tropical montane cloud forest in Costa Rica. Revista de Biología Tropical, San José, v. 58, n. 4, p. I489-I506, dez. 2010. 
HOMEIER, J.; BRECKLE, S. W.; GÜNTER, S.; ROLLENBECK, R. T.; LEUSCHNER, C. Tree diversity, forest structure and productivity along altitudinal and topographical gradients in a species-rich Ecuadorian Montane Rain Forest. Biotropica, Washington, v. 42, n. 2, p. 140 I48, mar. 2010.

KENT, M.; COKER, P. Vegetation Description and Analysis: a practical approach. London: Belhaven Press, 1992. 363 p.

KRÖMER, T.; ACEBEY, A.; KLUGE, J.; KESSLER, M. Effects of altitude and climate in determining elevational plant species richness patterns: a case study from Los Tuxtlas, Mexico. Flora, Haale, v. 208, n. 3, p. 197-2I0, mar. 2013.

MCCUNE, B.; MEFFORD, M. J. PC-ORD: multivariate analysis of ecological data: version 5.I. Gleneden Beach: MjM Software Design, 2006. I CD ROM.

MEIRELES, L. D.; SHEPHERD, G. J.; KINOSHITA, L. S. Variações na composição florística e na estrutura fitossociológica de uma floresta ombrófila densa altomontana na Serra da Mantiqueira, Monte Verde, MG. Revista Brasileira de Botânica, São Paulo, v. 3I, n. 4, p. 559-574, out./dez. 2008.

NEWTON, A. C. Forest Ecology and Conservation. Oxford: Oxford University Press, 2007. 454 p.

OLIVEIRA FILHO, A. T.; FLUMINHAN FILHO, M. Ecologia da vegetação do Parque Florestal Quedas do Rio Bonito. Cerne, Lavras, v. 5, n. 2, p. 5I-64, 1999.

OLIVEIRA FILHO, A. T.; FONTES, M. A. L. Patterns of floristic differentiation among Atlantic Forests in Southeastern Brazil and the influence of climate. Biotropica, Washington, v. 32, n. 4b, p. 793-810, dez. 2000.

PRADO, P. I.; LEWINSOHN, T. M.; CARMO, R. L.; HOGAN, D. J. Ordenação multivariada na ecologia e seu uso em ciências ambientais. Ambiente \& Sociedade, Campinas, v. 5, n. 10, p. I-I7, jan./jun. 2002.

RAHBEK C. The elevational gradient of species richness: a uniform pattern? Ecography, Copenhagen, v. 18, n. 4, p. 200-205, dez. 1995.
ROCHA, C. T. V.; CARVALHO, D. A.; FONTES, M. A. L.; OLIVEIRA FILHO, A. T.; BERG, E. V. D.; MARQUES, J. J. G. S. M. Comunidade arbórea de um continuum entre floresta paludosa e de encosta em Coqueiral, Minas Gerais, Brasil. Revista Brasileira de Botânica, São Paulo, v. 28, n. 2, p. 203-2।8, 2005.

SANTOS, S. C.; BUDKE, J. C.; MULLER, A. Regeneração de espécies arbóreas sob a influência de Merostachys multiramea Hack. (Poaceae) em uma floresta subtropical. Acta Botanica Brasilica, Feira de Santana, v. 26, n. I, p. 218-229, jan./mar. 2012.

SCHEER, M. B.; MOCOCHINSKI, A. Y.; RODERJAN, C. V. Estrutura arbórea da Floresta Ombrófila Densa Altomontana de serras do Sul do Brasil. Acta Botanica Brasilica, Feira de Santana, v. 25, n. 4, p. 735-750, out./dez. 201 I.

SOUZA, J. dos S.; ESPÍRITO-SANTO, F.del bon; FONTES, M. A. L.; OLIVEIRA FILHO, A. T. de; BOTEZELLI, L. Análise das variações florísticas e estruturais da comunidade arbórea de um fragmento de floresta semidecídua às margens do rio Capivari, Lavras-MG. Revista Árvore, Viçosa, v. 27, n. 2, p. I85-206, 2003.

TER BRAAK, C. J. F. The analysis of vegetation environment relationships by canonical correspondence analysis. Vegetatio, The Hage, v. 69, n. 3, p. 69-77, 1987.

TER BRAAK, C. J. F. Ordination. In: JONGMAN, R. H. G.; TER BRAAK, C. J. F.; TONGEREN, O. F. R. van (Ed.) Data analysis in community and landscape ecology. Cambridge: University Press Cambridge, 1995. p. 91-173.

WALTER $H$. Vegetation of the earth and ecological systems of the geo-biosphere. 3. ed. Berlin: SpringerVerlag, 1985. 318 p.

WHEELWRIGHT, N. T. Competition for dispersers, and the timing of flowering and fruiting in a guild of tropical trees. Oikos, Copenhagen, v. 44, n. 3, p. 465-477, Dec. 1985.

WHITTAKER, R. H. Communities and Ecosystems, 2. ed. New York: Macmillan, I 975. 385 p. 
